Louisiana State University

LSU Digital Commons

Faculty Publications

Department of Biological Sciences

$5-1-2006$

\title{
Nitric oxide transiently converts synaptic inhibition to excitation in retinal amacrine cells
}

\author{
Brian Hoffpauir \\ West Virginia University School of Medicine Morgantown \\ Emily McMains \\ Louisiana State University \\ Evanna Gleason \\ Louisiana State University
}

Follow this and additional works at: https://digitalcommons.Isu.edu/biosci_pubs

\section{Recommended Citation}

Hoffpauir, B., McMains, E., \& Gleason, E. (2006). Nitric oxide transiently converts synaptic inhibition to excitation in retinal amacrine cells. Journal of Neurophysiology, 95 (5), 2866-2877. https://doi.org/ 10.1152/jn.01317.2005

This Article is brought to you for free and open access by the Department of Biological Sciences at LSU Digital Commons. It has been accepted for inclusion in Faculty Publications by an authorized administrator of LSU Digital Commons. For more information, please contact ir@lsu.edu. 


\title{
Nitric Oxide Transiently Converts Synaptic Inhibition to Excitation in Retinal
}

\section{Amacrine Cells}

\author{
Brian Hoffpauir, ${ }^{2, *}$ Emily McMains, ${ }^{1, *}$ and Evanna Gleason ${ }^{1}$ \\ ${ }^{1}$ Department of Biological Sciences, Louisiana State University, Baton Rouge, Louisiana; and ${ }^{2}$ West Virginia University School of \\ Medicine, Morgantown, West Virginia
}

Submitted 14 December 2005; accepted in final form 30 January 2006

\begin{abstract}
Hoffpauir, Brian, Emily McMains, and Evanna Gleason. Nitric oxide transiently converts synaptic inhibition to excitation in retinal amacrine cells. J Neurophysiol 95: 2866-2877, 2006. First published February 8, 2006; doi:10.1152/jn.01317.2005. Nitric oxide (NO) is generated by multiple cell types in the vertebrate retina, including amacrine cells. We investigate the role of NO in the modulation of synaptic function using a culture system containing identified retinal amacrine cells. We find that moderate concentrations of $\mathrm{NO}$ alter $\mathrm{GABA}_{\mathrm{A}}$ receptor function to produce an enhancement of the GABAgated current. Higher concentrations of NO also enhance GABAgated currents, but this enhancement is primarily due to a substantial positive shift in the reversal potential of the current. Several pieces of evidence, including a similar effect on glycine-gated currents, indicate that the positive shift is due to an increase in cytosolic $\mathrm{Cl}^{-}$. This change in the chloride distribution is especially significant because it can invert the sign of GABA- and glycine-gated voltage responses. Furthermore, current- and voltage-clamp recordings from synaptic pairs of GABAergic amacrine cells demonstrate that NO transiently converts signaling at GABAergic synapses from inhibition to excitation. Persistence of the NO-induced shift in $\mathrm{E}_{\mathrm{Cl}^{-}}$in the absence of extracellular $\mathrm{Cl}^{-}$indicates that the increase in cytosolic $\mathrm{Cl}^{-}$is due to release of $\mathrm{Cl}^{-}$from an internal store. An NO-dependent release of $\mathrm{Cl}^{-}$from an internal store is also demonstrated for rat hippocampal neurons indicating that this mechanism is not restricted to the avian retina. Thus signaling in the CNS can be fundamentally altered by an NO-dependent mobilization of an internal $\mathrm{Cl}^{-}$store.
\end{abstract}

\section{N T R O D U C T I O N}

Amacrine cells are interneurons in the inner retina that extend laterally and form synaptic connections with bipolar, ganglion, and other amacrine cells. These lateral interactions play a key role in determining the nature of retinal output (for reviews, see Lagnado 1998; Taylor and Vaney 2003), so understanding the function and regulation of amacrine cells is critical to understanding retinal signal processing.

Nitric oxide (NO) has been implicated as a signaling molecule at all levels of the visual system (for review, see Cudeiro and Rivadulla 1999). Nitric oxide synthase (NOS) catalyzes the production of NO and citrulline from arginine. The neuronal form of this enzyme (nNOS) is constitutively expressed and stimulated by elevations of cytosolic $\mathrm{Ca}^{2+}$. In the canonical pathway, NO stimulates soluble guanylate cyclase (sGC) activity. NO is also known to affect target protein function through $S$-nitrosylation (Davis et al. 2001; Stamler et al. 1997) and by other direct interactions including formation of dinitrosyl iron complexes (Rogers et al. 2003).

\footnotetext{
* These authors contributed equally to this work.

Address for reprint requests and other correspondence: E. Gleason, Dept. of Biological Sciences, Rm. 202 Life Sciences Building, Louisiana State University, Baton Rouge, LA 70803 (E-mail: egleaso@1su.edu).
}

Neuronal NOS has been found in subsets of each class of neuron in the vertebrate retina (Blute et al. 1997; Chun et al. 1999; Fischer and Stell 1999; Kim et al. 1999; Rios et al. 2000; Shin et al. 1999), and NO itself has been detected in a similar array of retinal cells (Blute et al. 2000, 2003; Neal et al. 1998). In the chicken retina, a subset of amacrine cells expresses high levels of nNOS, and distinct sublaminae of nNOS labeling occur throughout the inner plexiform layer of the retina (Crousillac et al. 2003; Fischer and Stell 1999; Rios et al. 2000). Furthermore, measurements at the inner surface of the retina indicate that this tissue can generate high (micromolar) levels of NO (Donati et al. 1995; Groppe et al. 2003; Heiduschka and Thanos 1998).

The physiological effects of NO production have been examined for some cell types that signal in the inner retina. In the rabbit retina, NO reduces gap-junction coupling between AII amacrine cells and cone bipolar cells (Mills and Massey 1995). Wexler and colleagues (1998) have shown that NO depresses $\mathrm{GABA}_{\mathrm{A}}$ receptor function in cultured rat amacrine cells. In the ferret retina, recordings of ganglion cell activity reveal a dramatic NO-dependent decrease in light responses (Wang et al. 2003). Although effects of NO have been identified in multiple retinal cell types, the full range of $\mathrm{NO}$ function in the inner retina remains unknown.

To further examine how NO influences amacrine cell signaling, whole cell recordings were made from cultured GABAergic amacrine cells and amacrine cell synaptic pairs derived from embryonic chick retinae. We show that NO alters amacrine cell activity by affecting the functional properties of $\mathrm{GABA}_{\mathrm{A}}$ receptors and, much more dramatically, by converting inhibitory synapses to excitatory synapses through a GABA receptor-independent mechanism. This mechanism involves an $\mathrm{NO}$-induced redistribution of $\mathrm{Cl}^{-}$. Our results indicate that the redistribution of $\mathrm{Cl}^{-}$does not stem from $\mathrm{Cl}^{-}$moving across the plasma membrane but is instead due to release of $\mathrm{Cl}^{-}$from an internal compartment.

\section{METHODS}

\section{Cell culture}

Retinal cultures were prepared from 8-day-old chick embryos and maintained as previously described (Hoffpauir and Gleason 2002). Experiments were performed on isolated amacrine cells or isolated pairs of amacrine cells 6-14 days (EE 14 to PE 1) after plating. After 6 days in culture, these cells are considered to be mature, based on

The costs of publication of this article were defrayed in part by the payment of page charges. The article must therefore be hereby marked "advertisement" in accordance with 18 U.S.C. Section 1734 solely to indicate this fact. 
TABLE 1. External Solutions

\begin{tabular}{|c|c|c|c|c|c|c|c|c|c|c|}
\hline & $\mathrm{NaCl}$ & $\mathrm{KCl}$ & $\mathrm{CaOH}$ & $\mathrm{CaCl}_{2}$ & $\mathrm{MgCl}_{2}$ & HEPES & TEA-Cl & Glucose & NMG-Cl & $\mathrm{Na}$ Iseth \\
\hline Normal & 137.0 & 5.3 & & 3.0 & 0.4 & 10.0 & & 5.6 & & \\
\hline TEA-A & 116.7 & 5.3 & & 3.0 & 0.4 & 10.0 & 20.0 & 5.6 & & \\
\hline $0 \mathrm{~K}^{+}$ & 135.0 & & & 3.0 & & 10.0 & & 5.6 & & \\
\hline $0 \mathrm{Na}^{+}$ & & 5.0 & & 3.0 & & 10.0 & & 5.6 & 130.0 & \\
\hline $0 \mathrm{~K}^{+} / \mathrm{Na}^{+}$ & & & 3.0 & & 0.4 & 10.0 & & 5.6 & 135.0 & \\
\hline TEA-B & 87.4 & & & 3.0 & 0.4 & 10.0 & 20.0 & 5.6 & & 25.0 \\
\hline Low $\mathrm{Cl}^{-}$ & & 2.3 & & 3.0 & 0.4 & 10.0 & 5.0 & 5.6 & & 134.6 \\
\hline $0 \mathrm{Cl}^{-}$ & & & 3.0 & & & 10.0 & & 5.6 & & 135.0 \\
\hline TEA-H & 140.0 & 2.5 & & 2.0 & 1.0 & 10.0 & 20.0 & 10.0 & & \\
\hline $0 \mathrm{Cl}^{-}-\mathrm{H}$ & & & & & & 10.0 & & 10.0 & & 165.5 \\
\hline
\end{tabular}

Contents of external recording solutions are given in millimolar. The $\mathrm{pH}$ of external solutions was adjusted to 7.4 using an appropriate base. Glucose concentration was varied $\pm 10 \%$ to alleviate deviations from the normal osmolarity for some of the solutions. NMG, $N$-methyl-D-glucamine; TEA, tetraethylamonium; iseth, isethionate.

several physiological criteria including expression of the appropriate voltage- and ligand-gated ion channels (Huba and Hofmann 1991; Huba et al. 1992) and the formation of functional GABAergic synapses with other GABAergic amacrine cells. The properties of the amacrine-to-amacrine cell GABAergic synapses formed in culture have been previously characterized (Gleason et al. 1993). The uniformity of neurotransmitter phenotype indicates that the amacrine cells in culture represent a subset of amacrine cell phenotypes found in the intact retina.

Hippocampal cultures were made from 18-day-old rat (Fischer 344) embryos. Micro-dissected hippocampal tissue was obtained from Neuromics (Bloomington, MN) and prepared and maintained according to the supplier's protocols. Recordings from single hippocampal neurons were made after 4-7 days in culture. No physiological assessments of the relative maturity of these cells have been made. According to their developmental timeline alone, they would be considered embryonic (EE 22-EE 25).

\section{Electrophysiology}

Whole cell recordings were made using an Axopatch 1-D amplifier, Digidata 1322A data-acquisition board, and Clampex 9.2 software (Axon Instruments, Union City, CA). A reference $\mathrm{Ag} / \mathrm{AgCl}$ pellet in $3 \mathrm{M} \mathrm{KCl}$ was connected to the culture dish via an agar bridge containing $3 \mathrm{M} \mathrm{KCl}$. Patch electrodes were pulled from thick-walled borosilicate glass $(1.5 \mathrm{~mm} \mathrm{OD}, 0.86 \mathrm{~mm}$ ID; Sutter Instruments, Novato, CA) using a P-97 Flaming/Brown Puller (Sutter Instruments). Tip resistance values were 5-10 $\mathrm{M} \Omega$ for ruptured-patch recordings and 3-5 M $\Omega$ for perforated-patch recordings as measured in the bath. All recordings were made at room temperature $\left(22-24^{\circ} \mathrm{C}\right)$ and were corrected for junction potential error. Voltage ramp data were leaksubtracted. Because we used both perforated- and ruptured-patch to study the NO-shift in $E_{\mathrm{GABA}}$ (see RESULTS), we wanted to determine whether the recording configuration had an effect on the amplitude of the shift. To achieve this, we recorded NO-induced shifts in $E_{\mathrm{GABA}}$ on
1 day with one batch of NO solution. For these experiments, we alternated between the two recording configurations and found no significant differences in the amplitude of the shifts $(n=3$ in each configuration; $P=0.999$ ).

\section{Solutions}

Unless otherwise indicated, all reagents were purchased from Sigma, St. Louis, MO. GABA application was achieved in 10-20 ms through computer-controlled perfusion barrel movements. This method was also used to switch between normal and zero external $\mathrm{Cl}^{-}$ for the experiment depicted in Fig. 8A. All other solution changes were achieved in $\sim 500 \mathrm{~ms}$ by opening and closing the valves upstream of a manifold feeding one common barrel. The compositions of external and internal solutions are shown in Tables 1 and 2 , respectively. TTX $(300 \mathrm{nM})$ and $\mathrm{LaCl}_{3}(25-50 \mu \mathrm{M})$ were added to external solutions (with the exception of the $0 \mathrm{Cl}^{-}$external solution) for single-cell voltage clamp (but not current clamp) recordings to block voltage-gated $\mathrm{Na}^{+}$and $\mathrm{Ca}^{2+}$ currents, respectively. For ruptured-patch recordings, the following reagents were added to internal solutions $\left(\mathrm{Cs}^{+}-\mathrm{A}\right.$, unless otherwise indicated): $50 \mathrm{U} / \mathrm{ml}$ creatine phosphokinase, $3 \mathrm{mM}$ adenosine $5^{\prime}$-triphosphate (ATP) dipotassium salt, $1 \mathrm{mM}$ ATP-disodium salt, $20 \mathrm{mM}$ phosphocreatine (Calbiochem, La Jolla, CA), 2 mM guanosine 5'-triphosphate (GTP) sodium salt. For perforated-patch recordings, either amphotericin B (synaptic pairs, Fig. 4) or gramicidin (Figs. 5 and 6) were added to normal internal or $\mathrm{Cs}^{+}$internal, respectively, to a final concentration of 10 $\mu \mathrm{g} / \mathrm{ml}$.

$S$-Nitroso- $N$-acetyl-D,L-penicillamine (SNAP), 1-hydroxy-2-oxo-3( $N$-ethyl-2-aminoethyl)-3-ethyl-1-triazene (NOC-12), 2,2'-(hydroxynitrosohydrazino)bisethanamine (NOC-18), and 2-(4-carboxyphenyl)4,4,5,5-tetramethylimidazoline-1-oxyl-3-oxide, sodium salt (carboxyPTIO) were obtained from Dojindo Molecular Technologies (Gaithersburg, MD) and stored at $-20^{\circ} \mathrm{C}$. The final $\mathrm{pH}$ of external solutions containing the nitric oxide donors was readjusted to 7.4 with

TABLE 2. Internal solutions

\begin{tabular}{|c|c|c|c|c|c|c|c|c|c|c|}
\hline & Cs Acetate & $\mathrm{CsCI}$ & $\mathrm{K}$ Acetate & $\mathrm{KCl}$ & $\mathrm{CaCl}_{2}$ & $\mathrm{MgCl}_{2}$ & HEPES & EGTA & $\mathrm{NaCl}$ & MES \\
\hline $\mathrm{Cs}^{+}-\mathrm{A}$ & 100.0 & 10.0 & & & 0.1 & 2.0 & 10.0 & 1.1 & & \\
\hline $\mathrm{Cs}^{+}-\mathrm{B}$ & 135.0 & 10.0 & & & 0.1 & 2.0 & 10.0 & 1.1 & & \\
\hline $\mathrm{High} \mathrm{Cl}^{-}$ & & 110.0 & & & 0.1 & 2.0 & 10.0 & 1.1 & & \\
\hline Normal & & & 145.0 & 5.0 & 0.1 & 2.0 & 10.0 & 1.1 & & \\
\hline MES & & & & & & & 10.0 & & 10.0 & 127.0 \\
\hline $0 \mathrm{Cl}^{-}$ & & & & & & & 10.0 & & & 135.0 \\
\hline $\mathrm{Cs}^{+}-\mathrm{H}$ & 130.0 & 15.0 & & & 0.1 & 3.0 & 10.0 & 1.1 & & \\
\hline
\end{tabular}

Contents of internal recording solutions are given in millimolar. Methane sulfonate is abbreviated MES. Internal solutions $\mathrm{Cs}^{+}-\mathrm{A}_{\text {and }}$ high $\mathrm{Cl}^{-}$were supplemented with the ATP regeneration system components (see METHODS). $\mathrm{Cs}^{+}-\mathrm{H}$ was supplemented with $2 \mathrm{mM}$ disodium ATP. The pH of the internal solutions was adjusted to 7.4 using an appropriate acid or base. 
$\mathrm{NaOH}$ (SNAP and NOC 12). 1H-[1,2,4] oxadiazolo[4,3-a]quinoxalin1-one (ODQ) was prepared at $10 \mathrm{mM}$ in DMSO. Furosemide and bumetanide were prepared as $300 \mathrm{mM}$ stocks in DMSO.

\section{NO-bubbled solutions}

Pure NO solutions were prepared by bubbling solutions with argon for $15 \mathrm{~min}$ followed by $15 \mathrm{~min}$ of bubbling with pure soda limefiltered NO. NO solutions were tightly sealed, protected from light, and stored at $4{ }^{\circ} \mathrm{C}$. Although the method for preparing $\mathrm{NO}$ was standardized, the efficacy of different batches was variable. For most experiments, injections between 10 and $50 \mu \mathrm{l}$ were able to elicit shifts of $15-35 \mathrm{mV}$. When standard volumes of a batch of NO solution became less efficient, a new batch was obtained. The NO solutions were delivered into the perfusion system manually with a Hamilton syringe via in-line injections $(10-50 \mu \mathrm{l}$ depending on potency, see following text). In-line injection of dye-containing solutions indicated that NO exposure was limited to $1-3 \mathrm{~s}$ with most of the NO arriving in the first $500 \mathrm{~ms}$. NO was bubbled into either $\mathrm{H}_{2} \mathrm{O}$ or TEA external. No differences in the effects of $\mathrm{NO}$ in the two solutions were observed. For synaptic recordings, NO was bubbled into a $40 \mathrm{mM}$ HEPES solution to minimize low pH effects on $\mathrm{Ca}^{2+}$ channels and other synaptic proteins. The concentration of NO in these solutions was measured using an ISO-NO meter (NOMK2 system) with an ISO-NOP electrode (World Precision Instrument, Sarasota, FL) for a batch and volume that was demonstrated to be effective in eliciting cellular responses. The mean NO concentration measured at the perfusion outlet was $2.0 \pm 0.3 \mu \mathrm{M}$. This value represents the upper limit of NO coming in contact with a cell. For SNAP solutions, $\sim 100$ $\mathrm{nM}$ NO was detected in external solution containing $250 \mu \mathrm{M}$ SNAP ( $2 \mathrm{~h}$ after preparation). With the exception of Fig. 1, the data shown were obtained using NO-bubbled solutions.

"Air-exposed" NO solutions were made by exposing NO-bubbled solution to air for $\geq 10-30 \mathrm{~min}$. For both fresh and air-exposed NO solutions, $\mathrm{pH}$ values typically ranged between 2 and 3 . Injections of the appropriate amount of $\mathrm{pH} 2.5$, NO-free solutions were routinely used as controls and none of the effects reported here were reproduced by low $\mathrm{pH}$ alone. Although extreme care has been taken to standardize the preparation, handling and injections of these volatile solutions, some variability remains. As such, only those cells receiving the same volumes, from the same batch of NO-bubbled solutions were used for quantitative comparisons. Data are reported as means $\pm \mathrm{SD}$ and statistical significance was determined using the $t$-test. Data shown in Figs. $5, B$ and $D$, and $6 F$ were analyzed using the paired $t$-test.

\section{RES U L T S}

\section{Effects of NO on GABA-gated currents}

To explore the effects of NO, we recorded whole cell $\mathrm{GABA}_{\mathrm{A}}$ receptor currents (Hoffpauir and Gleason 2002) from individual amacrine cells. For these experiments, $\mathrm{Cs}^{+}-\mathrm{A}$ internal and TEA-A external solutions were used, and recordings were made in the ruptured-patch recording configuration. Under these conditions, we find that NO produces three effects in amacrine cells. First, moderate NO donor concentrations (250 $\mu \mathrm{M}$ SNAP, $100 \mathrm{nM}$ NO, see METHODs) caused a small $(\sim 15 \%)$ enhancement of the GABA-gated current amplitude that was not due to alteration in the reversal potential of the current $\left(E_{\mathrm{GABA}}\right.$, Fig. 1). Similar effects were observed with NOC $12(250 \mu \mathrm{M})$ and NOC $18(300 \mu \mathrm{M}$, not shown). The SNAP-dependent enhancement was significantly inhibited in the presence of the NO scavenger carboxy-PTIO, indicating that $\mathrm{NO}$ rather than donor end products underlie the $\mathrm{GABA}_{\mathrm{A}}$ current enhancement (Fig. $1 C, P=0.002$ ).

Second, higher concentrations of NO (hundreds of nanomolar to low micromolar, NO-bubbled solutions, see METHODS) produced a transient (1-3 s), GABA-independent inward cur-
A

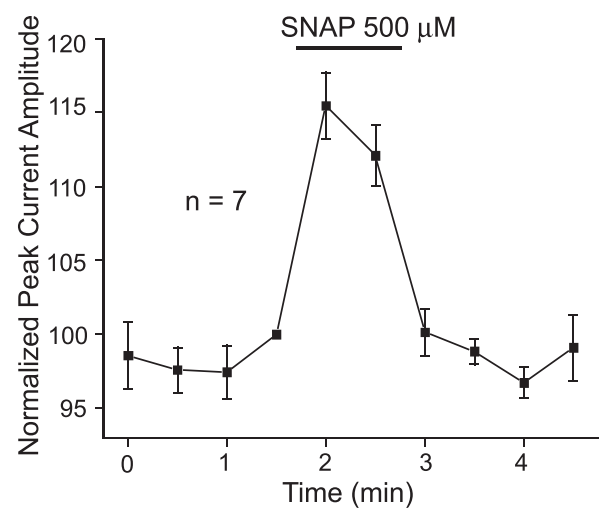

C

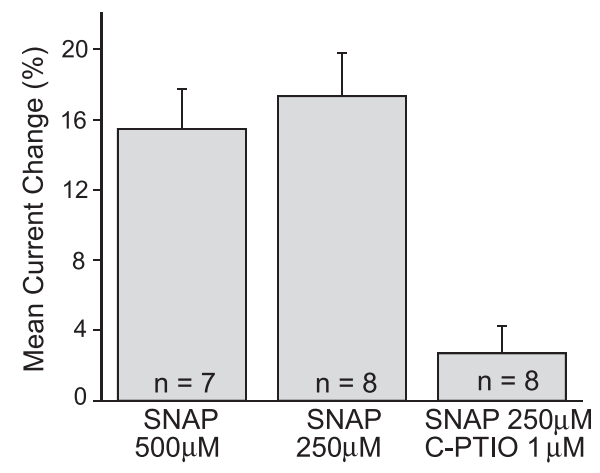

B

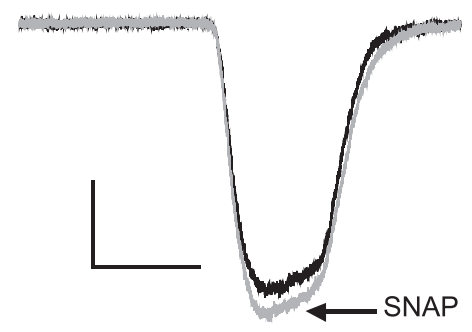

D

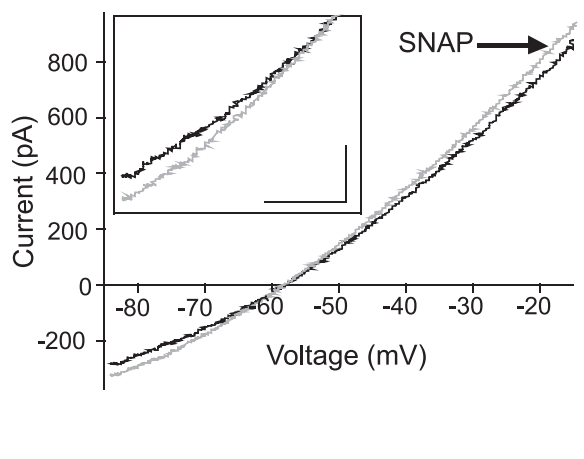

FIG. 1. Moderate concentrations of nitric oxide (NO) enhance $\mathrm{GABA}_{\mathrm{A}}$ receptor function. $A$ : peak current amplitudes of inward currents elicited by 500-ms applications of GABA (20 $\mu \mathrm{M})$ are normalized to the current amplitude just prior to application of $S$-nitroso- $N$-acetylD,L-penicillamine (SNAP). $B$ : whole cell voltage-clamp recordings of GABA-gated currents from a representative amacrine cell recorded before (black trace) and in the presence of (gray trace) SNAP. Scale bars are $100 \mathrm{pA}$ and 500 ms. $C$ : mean response amplitudes from cells exposed to 2 concentrations of SNAP and in the presence of the NO scavenger, 2-(4-carboxyphenyl)-4,4,5,5-tetramethylimidazoline-1-oxyl3-oxide, sodium salt (carboxy-PTIO). Mean current change is calculated as the percent difference of GABA-gated current amplitudes measured immediately before SNAP application compared with those measured after $30 \mathrm{~s}$ of exposure to SNAP. D: leak-subtracted currents elicited by voltage ramps delivered in the presence of GABA before (black trace) and in the presence of (gray trace) SNAP $(500 \mu \mathrm{M})$. Scale bars are $100 \mathrm{pA}$ and $10 \mathrm{mV}$. All recordings were made with $\mathrm{Cs}^{+}-\mathrm{A}$ internal and TEA-A external in the ruptured-patch configuration. 
A

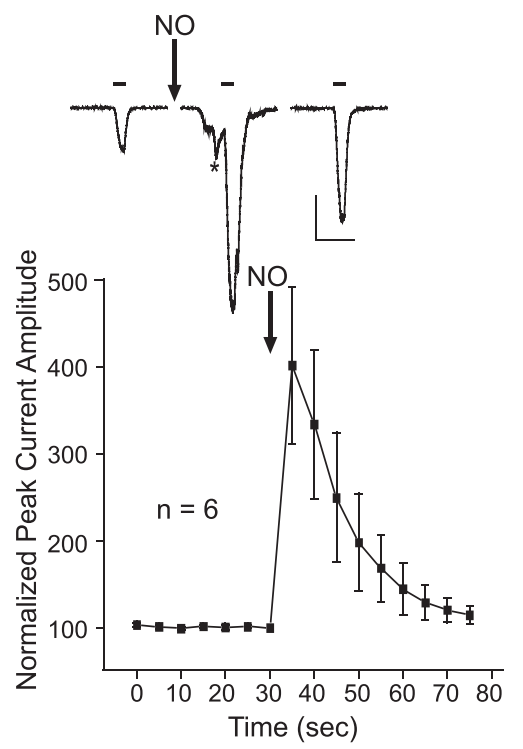

C

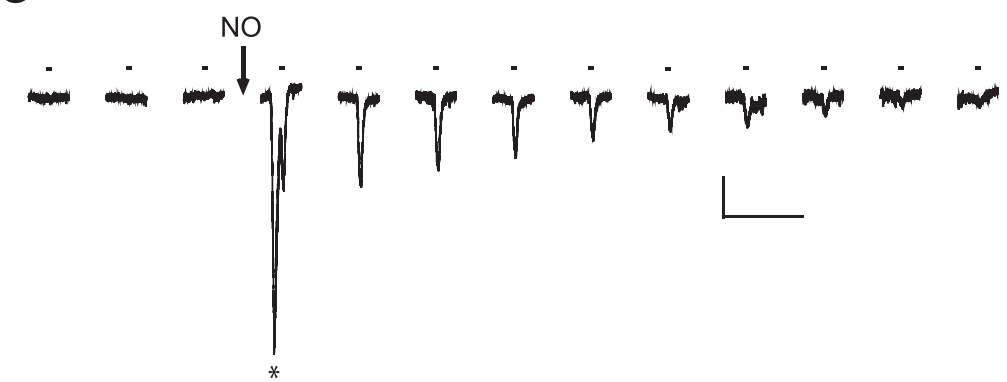

D

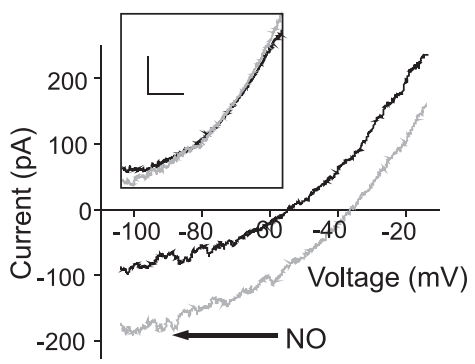

F

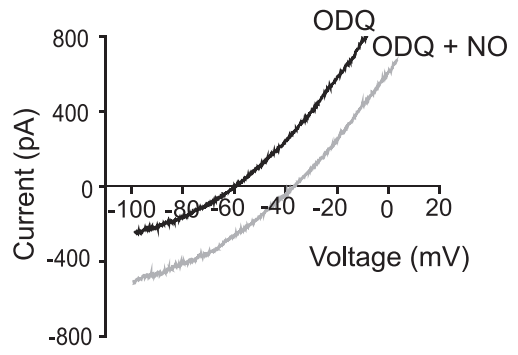

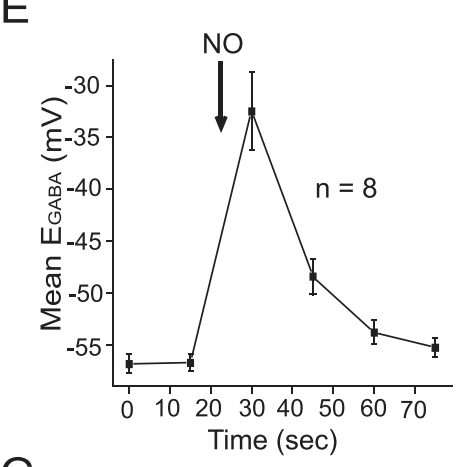

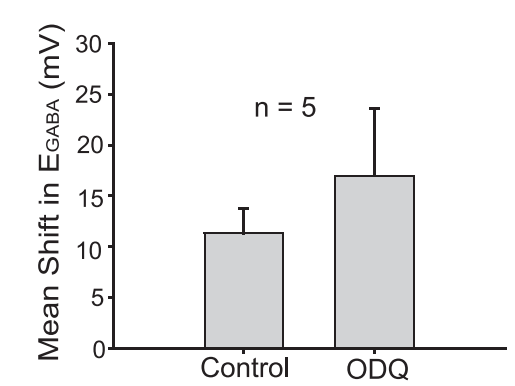

B
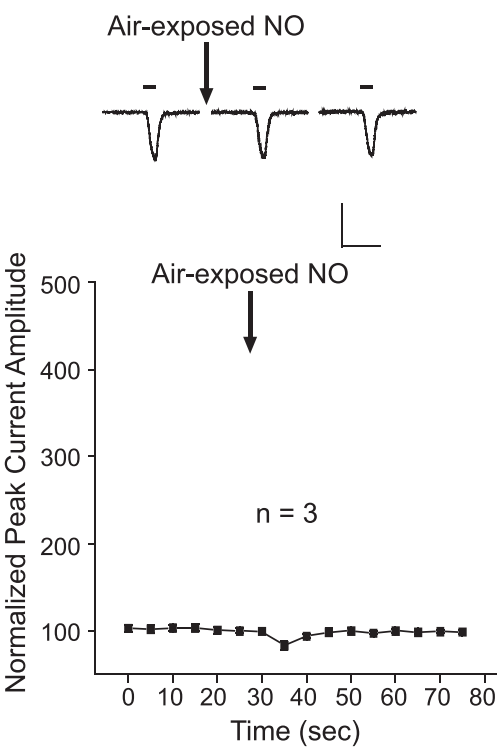

FIG. 2. Higher concentrations of NO promote a positive shift in $E_{\mathrm{GABA}}$. $A$ and $B$, top traces: raw data from rupturedpatch voltage-clamp recordings of GABA-gated currents from a representative cell before and after $\mathrm{NO}$ application. GABA pulses $(20 \mu \mathrm{M})$ were $300 \mathrm{~ms}$ in duration and are indicated by horizontal bars. $A$ : whole cell, voltage-clamp recordings $\left(\mathrm{Cs}^{+}-\mathrm{A}\right.$ internal and TEA-A external) of GABA-gated currents reveal that higher concentrations of NO induce a transient, several-fold enhancement of GABA-gated currents. *, NOdependent current observed prior to the 2nd GABA application. $B$ : same experiment as in $A$, using air-exposed NO solution. Raw data in $A$ and $B$ are from same cell. Scale bars are $150 \mathrm{pA}, 1$ s. $C$ : amacrine cell is held at the predicted $E_{\mathrm{GABA}}$. GABA is applied for $300 \mathrm{~ms}$ during each trace. No GABAgated currents are observed until application of NO. *, NOdependent current. Scale bars are 25 pA, 5 s. $D$ : voltage ramps in GABA were delivered before and after addition of NO. Leak-subtracted currents reveal a shift in $E_{\mathrm{GABA}}$ after NO application (gray trace). Inset: subtraction of the NO-induced shift in reversal potential reveals an increase in the slope of the GABA-gated current-voltage relationship after NO injection (gray trace). Scale bars are $100 \mathrm{pA}, 20 \mathrm{mV}$. E: mean $E_{\mathrm{GABA}}$ values are plotted over time. $F$ : representative GABA-gated currents from voltage ramps delivered after a 11-min treatment with $1 \mathrm{H}$-[1,2,4] oxadiazolo[4,3-a]quinoxalin-1-one (ODQ; 2 $\mu \mathrm{M})$. Black trace, before NO injection; Gray trace, after NO injection. $G$ : ODQ did not block the NO-induced shift in $E_{\mathrm{GABA}}(P=0.83, n=5)$. rent (Figs. 2, $A$ and $C$, and $7 B i$, asterisks). Based on reversal potential measurements, this NO-dependent, GABA-independent, inward current is a cation current $\left(E_{\mathrm{rev}}=+23.4 \pm\right.$ $6.6 \mathrm{mV}, n=5)$.
The third effect of NO is the most dramatic and will form the main focus of this work. We find that brief (1-3 s) exposure to higher NO concentrations also produced a several-fold enhancement of the GABA-gated current (Fig. 2A) due to a 
transient positive shift in $\mathrm{E}_{\mathrm{GABA}}$ (shift $=24.8 \pm 4.2 \mathrm{mV}$; Fig. $2, C-E)$. The slight inhibition of GABA-gated current amplitude after exposure to air-exposed $\mathrm{NO}$ solution (Fig. 2B) is most likely due to the acidic nature of these solutions (see METHODS) (Huang and Dillon 1999). Note that the time course of recovery for the (higher concentration) NO-induced current enhancement (Fig. 2A) is consistent with the recovery time course for $E_{\mathrm{GABA}}$ (Fig. $2 E$ ). Similar shifts in $E_{\mathrm{GABA}}$ were obtained with high concentrations $(2 \mathrm{mM})$ of the NO donor NOC 12 (not shown) indicating that the mechanism responsible for the shift in $E_{\mathrm{GABA}}$ can be activated by either NO delivery method as long as the concentration of NO is in the correct concentration range. A small increase in the slope of the I-V relationship for the GABA-gated current (1st NO effect) was also detectable with higher NO concentrations (Fig. $2 D$, inset). The role of soluble guanylate cyclase (sGC) activation in the NO-induced shift in $E_{\mathrm{GABA}}$ was investigated using the sGC inhibitor ODQ. Prolonged ( $>10 \mathrm{~min}$ ) preincubation with the inhibitor did not block the NO-induced shift in $E_{\mathrm{GABA}}$ indicating that sGC activity is not involved in this mechanism (Fig. 2, $F$ and $G$ ). The nonsignificant trend toward larger responses in ODQ suggests that basal sGC activity might have a suppressive effect on the mechanism underlying the shift in $E_{\mathrm{GABA}}$. Finally, the NO-dependent current (2nd NO effect) may be related to the shift in $E_{\mathrm{GABA}}$ but does not seem to be an absolute requirement because we have observed the shift in the absence of this current.

\section{NO-induced shift in $E_{G A B A}$ is due an elevation in cytosolic $\mathrm{Cl}^{-}$}

Three possible explanations for the NO-induced shift in $E_{\mathrm{GABA}}$ were examined: a change in ion selectivity of the $\mathrm{GABA}_{\mathrm{A}}$ receptors, the introduction of another permeant anion into the cell, or an increase in intracellular $\mathrm{Cl}^{-}$concentration. To determine whether NO increases the selectivity of $\mathrm{GABA}_{\mathrm{A}}$ receptors to acetate (the only other anion in the internal solution), internal acetate was substituted with methanesulfonate, a bulky anion unlikely to permeate the receptors. This substitution, however, did not prevent the NO-induced shift in $E_{\mathrm{GABA}}$ as indicated by the several-fold enhancement of the GABA-gated current (Fig. 3A). This suggests that the NOinduced shift in $E_{\mathrm{GABA}}$ is not due to a change in the ion selectivity of the channels.

The shift could be due to the production of nitrate $\left(\mathrm{NO}_{3}^{-}\right)$ that occurs when $\mathrm{NO}$ reacts with $\mathrm{O}_{2}$ and $\mathrm{H}_{2} \mathrm{O}$. Because $\mathrm{NO}_{3}^{-}$is quite permeable through $\mathrm{GABA}_{\mathrm{A}}$ receptors (Biscoe and Duchen 1985; Bormann et al. 1987), it is possible that trapped cytosolic $\mathrm{NO}_{3}^{-}$(from inwardly diffusing $\mathrm{NO}$ ) contributes to the shift in $E_{\mathrm{GABA}}$. Furthermore, although the recording solutions are $\mathrm{HCO}_{3}^{-}$-free, it is also possible that NO transiently stimulates the production of $\mathrm{HCO}_{3}^{-}$, another anion that can permeate $\mathrm{GABA}_{\mathrm{A}}$ receptors (Bormann et al. 1987). In zero $\mathrm{Cl}^{-}$internal and zero $\mathrm{Cl}^{-}$external solutions, no GABA-gated currents were observed either before or after application of NO (Fig. 3B). This argues against the possibility that the shift is due to an increase in intracellular $\mathrm{NO}_{3}^{-}$, or $\mathrm{HCO}_{3}^{-}$, or any other permeant anion.

If the effect of $\mathrm{NO}$ is to raise internal $\mathrm{Cl}^{-}$, then a similar shift in reversal potential should also be observed when glycine receptors are activated. Agonist-gated currents were elicited

\section{A}

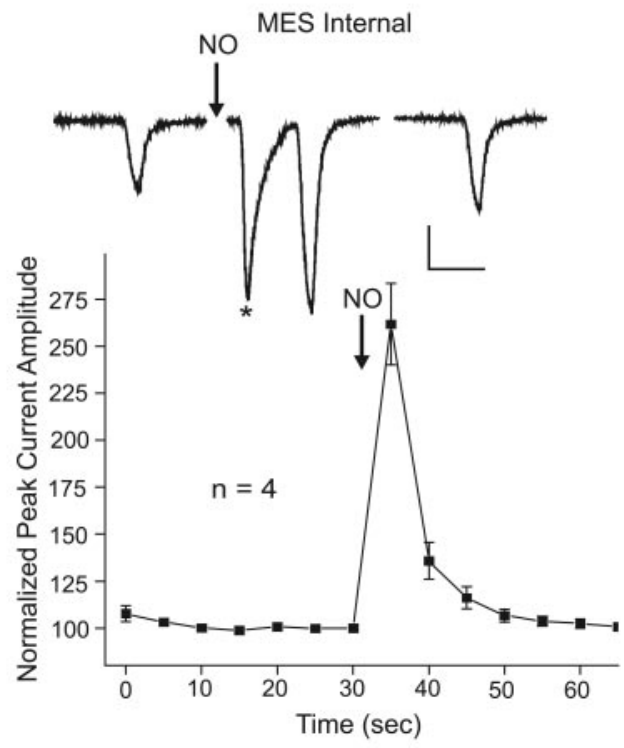

B

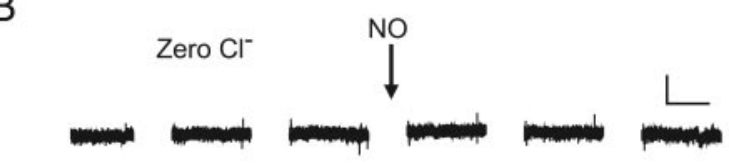

C

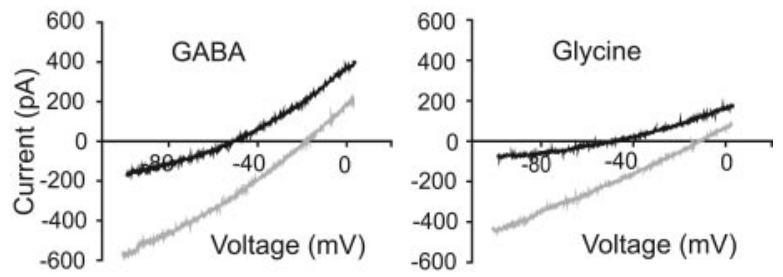

D

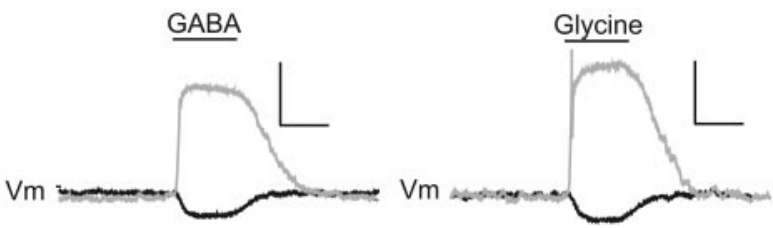

FIG. 3. The shift in $E_{\mathrm{GABA}}$ is due to an NO-induced increase in cytosolic $\mathrm{Cl}^{-}$. A: substituting methanesulfonate for acetate in the $\mathrm{Cs}^{+}$internal (MES internal) solution does not prevent NO-induced enhancement. The NO-dependent current (asterisk) is also observed with this internal solution. Experiment conducted as in Fig. 2, $A$ and $B$, with horizontal bars indicating time course of GABA application. $B$ : ruptured-patch, voltage-clamp recordings of an amacrine cell held at $-70 \mathrm{mV}$ with $0 \mathrm{Cl}^{-}$internal and external solutions. GABA is applied for $300 \mathrm{~ms}$ in each trace (horizontal bars). Time scale applies only to current traces (start-to-start intervals are $5 \mathrm{~s}$ ). An NO-dependent current was recorded immediately after the NO application (not shown). Scale bars ( $A$ and $B)$ are $10 \mathrm{pA}, 1 \mathrm{~s}$. $C$ : leak-subtracted currents from voltage ramps delivered in GABA $(20 \mu \mathrm{M})$ and glycine $(20 \mu \mathrm{M})$ before (black trace) and after (gray trace) addition of NO. ( $\mathrm{Cs}^{+}-\mathrm{A}$ internal and TEA-A external solutions). $D$ : current-clamp recordings from a different cell $\left(V_{\text {rest }}=-65 \mathrm{mV}\right)$ show the voltage responses to GABA and glycine before (black trace) and after (gray trace) exposure to NO. An action potential occurs at the beginning of the glycine-induced depolarization. Scale bars are $10 \mathrm{mV}, 500 \mathrm{~ms}$ (normal internal and normal external solutions). 
with pulses of $20 \mu \mathrm{M}$ glycine or $20 \mu \mathrm{M}$ GABA delivered during voltage ramps. Addition of NO caused a shift in the reversal potential to more positive values for both agonists (Fig. $3 C$; GABA shift: $33.6 \pm 11.5 \mathrm{mV}$; glycine shift: $30.0 \pm$ $14.0 \mathrm{mV} ; P=0.67 ; n=5$ ), indicating that $\mathrm{NO}$ is stimulating a redistribution of $\mathrm{Cl}^{-}$in these cells. An increase in the slope of the glycine-gated current was also observed, indicating an enhancing effect of NO on glycine receptor function. The ability to change the internal $\mathrm{Cl}^{-}$concentration in the face of diffusion from the pipette may be unexpected, but it is not unprecedented. $\mathrm{Cl}^{-}$transport has been shown to be effective in opposing diffusion from the recording pipette (Staley et al. 1996) and changes in cytosolic $\mathrm{Cl}^{-}$have been measured by optical methods in the ruptured patch recording configuration (Isomura et al. 2003). It is also possible that the redistribution of $\mathrm{Cl}^{-}$is not a global event, but one that occurs locally, possibly in neuronal processes.

Current-clamp recordings were made to determine how the NO-induced shift in $\mathrm{E}_{\mathrm{Cl}^{-}}$affects GABA- and glycine-dependent changes in membrane potential (Fig. 3D). Resting membrane potentials were $-60.1 \pm 13.2 \mathrm{mV}(n=5)$. Under control conditions, application of GABA or glycine hyperpolarized these cells to $-70.9 \pm 2.7$ and $-68.7 \pm 5.3 \mathrm{mV}$, respectively. For the first agonist pulse after $\mathrm{NO}$ application, GABA depolarized the cells to $-31.8 \pm 25.2 \mathrm{mV}$ and glycine depolarized the cells to $-34.4 \pm 18.4 \mathrm{mV}$. One cell responded to both GABA (not shown) and glycine (Fig. 3D) with a single action potential followed by a steady depolarization. This is the typical voltage response for these cells given sufficient depolarization (Gleason et al. 1993). It is important to note, however, that action potentials are not required for $\mathrm{Ca}^{2+}$-dependent neurotransmitter release from these cells (Gleason et al. 1993). These current-clamp recordings demonstrate that NO can change the sign of whole-cell voltage responses to GABA and glycine.

\section{NO-induced shift in $E_{\mathrm{Cl}^{-}}$occurs at synapses}

To examine the influence of NO specifically at retinal amacrine cell synapses, dual perforated-patch recordings were made from pairs of cultured GABAergic amacrine cells. It is well established that GABAergic amacrine cell synapses are normally inhibitory, both in the retina (Lagnado 1998) and in these cultures (Gleason et al. 1993). Recordings from isolated pairs of amacrine cells demonstrate that brief exposure to NO can transiently change the sign of GABAergic synapses (Fig. 4). With both pre- and postsynaptic cells in the voltage-clamp configuration, a depolarizing voltage step in the presynaptic cell produced a small outward current in the postsynaptic cell. After NO, postsynaptic currents become inward indicating an excitatory effect on the postsynaptic cell (Fig. $4 A$, gray trace). The relatively small, noisy postsynaptic currents are consistent with the low release rates described for these synapses in culture (Gleason et al. 1993) and for GABAergic amacrine cell synapses in the intact retina (Zheng et al. 2004). When the postsynaptic cell is switched to current clamp, the postsynaptic response is barely detectable because under control conditions, the resting potential of the cell $(-67 \mathrm{mV})$ is very near the calculated $\mathrm{E}_{\mathrm{Cl}^{-}}(-70 \mathrm{mV})$. After $\mathrm{NO}$, the postsynaptic voltage response is depolarizing (Fig. $4 B$, gray trace). NO-dependent, excitatory synaptic responses were detected in all pairs exam-
A

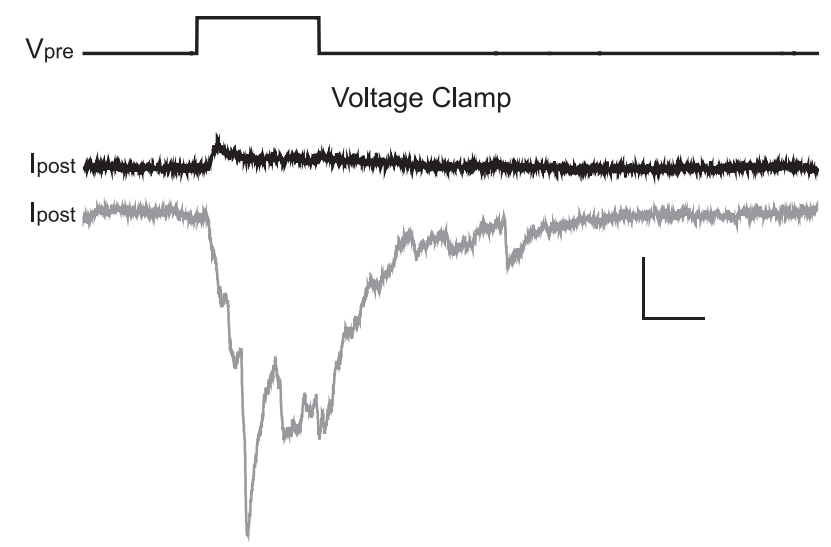

B

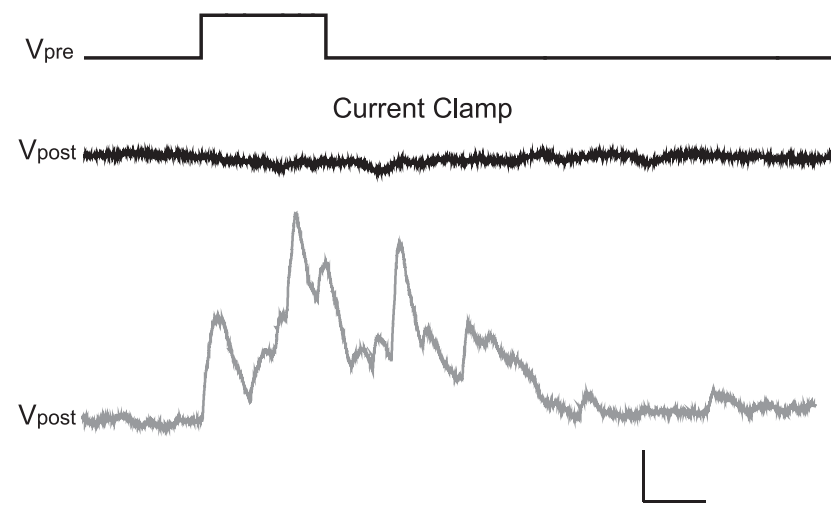

FIG. 4. NO inverts the sign of GABAergic synapses. A: both pre- and postsynaptic cells were voltage clamped. Only data from the postsynaptic cell are shown. Under control conditions, depolarization of the presynaptic cell from -70 to $-10 \mathrm{mV}$ elicits a small outward current in the postsynaptic cell (black trace, $V_{\text {hold }}=-66 \mathrm{mV}$ ). After NO, depolarization of the presynaptic cell produces a large inward current in the postsynaptic cell (gray trace). Traces immediately after NO application were contaminated by the NO-dependent current. The trace shown was collected $\sim 15 \mathrm{~s}$ after NO. NO exposure time is 2-3 s (see METHODS) Scale bars are 200 pA, $50 \mathrm{~ms}$. B: current-clamp recordings from the same postsynaptic cell as in $A$. Depolarization of the presynaptic cell (to $0 \mathrm{mV}$, in voltage clamp) produces only a slight hyperpolarization in the postsynaptic cell (black trace) because the resting potential of this cell (-67 $\mathrm{mV})$ is near the predicted $\mathrm{E}_{\mathrm{Cl}^{-}}(-70 \mathrm{mV})$. A record collected $\sim 20 \mathrm{~s}$ after $\mathrm{NO}$ exposure shows that the postsynaptic response is now depolarizing (gray trace). Scale bars are $5 \mathrm{mV}, 100 \mathrm{~ms}$. Records were collected with normal internal containing amphotericin B and TEA-A external solutions.

ined $(n=5)$. Postsynaptic responses to subsequent presynaptic depolarizations were omitted from Fig. 4 for clarity, but they show that recovery from the NO-dependent shift in $\mathrm{E}_{\mathrm{Cl}^{-}}$occurs over a similar time frame as observed in recordings of whole cell GABA-gated currents in single amacrine cells (see Fig. 2, $A$ and $E$ ). It is possible that NO has other, as yet uncharacterized effects on amacrine cell synapses (Ahern et al. 2002; Hölscher 1997), but the key observation here is that the shift in $\mathrm{E}_{\mathrm{Cl}^{-}}$found in whole cell recordings also occurs at synapses.

\section{$\mathrm{NKCC}$ does not mediate the increase in cytosolic $\mathrm{Cl}$}

What mechanism underlies the increase in cytosolic $\mathrm{Cl}^{-}$? The plasma membrane $\mathrm{Na}^{+}-\mathrm{K}^{+}-\mathrm{Cl}^{-}$co-transporter (NKCC) and the $\mathrm{K}^{+}-\mathrm{Cl}^{-}$co-transporter $(\mathrm{KCC} 2)$ are $\mathrm{Cl}^{-}$co-transport mechanisms known to regulate the distribution of $\mathrm{Cl}^{-}$across neuronal plasma membranes (Kakazu et al. 2000; Russell 
2000). It is now well established that changes in $\mathrm{Cl}^{-}$cotransporter expression determine the effects of GABA during development (for review, see Payne et al. 2003). In the adult retina, $\mathrm{E}_{\mathrm{Cl}^{-}}$varies among cell types and subcellular locations, and this correlates with the expression pattern of NKCC and KCC2 (Vardi et al. 2000). Furthermore, the response properties of retinal starburst amacrine cells are dependent on the activity of NKCC and KCC2 (Gavrikov et al. 2003). Given the established role of these transporters in determining $\mathrm{E}_{\mathrm{Cl}^{-}}$, we investigated the role of $\mathrm{NKCC}$ and $\mathrm{KCC} 2$ in the NO-induced shift in $\mathrm{E}_{\mathrm{Cl}^{-}}$.

NKCC typically transports $2 \mathrm{Cl}^{-}, 1 \mathrm{Na}^{+}$, and $1 \mathrm{~K}^{+}$into the cell and the neuron specific $\mathrm{K}^{+}-\mathrm{Cl}^{-}$co-transporter, $\mathrm{KCC} 2$, transports $1 \mathrm{Cl}^{-}$and $1 \mathrm{~K}^{+}$out of the cell. Thus the NO-induced shift in $E_{\mathrm{GABA}}$ could be due to an increase in NKCC activity or a decrease in $\mathrm{KCC} 2$ activity. To determine if these mechanisms were involved, perforated-patch recordings were made with $\mathrm{Cl}^{-}$-impermeant gramicidin in the pipette and the co-transport inhibitors, bumetanide $(300 \mu \mathrm{M})$ and furosemide $(300 \mu \mathrm{M})$ were used to block NKCC and KCC2 activity. Both inhibitors shifted $\mathrm{E}_{\mathrm{Cl}^{-}}$to more negative potentials, indicating a dominant inhibitory effect on NKCC (Fig. 5, $A$ and $C$ ). Neither blocker, however, inhibited the NO-induced shift in $\mathrm{E}_{\mathrm{Cl}^{-}}$(Fig. 5, $B$ and $D$ ). To asses the variability of responses under control conditions, the effects of two separate NO applications were also examined and we found no significant difference between the two trials $(P=0.69, n=5$, not shown). At lower concentrations $(10 \mu \mathrm{M})$, bumetanide is selective for NKCC (Russell 2000). In similar experiments, bumetanide at $10 \mu \mathrm{M}$ was also ineffective in blocking the shift in $\mathrm{E}_{\mathrm{Cl}^{-}}$(not shown).

Removal of the externally required co-transported ions shifted $\mathrm{E}_{\mathrm{Cl}^{-}}$to more negative potentials. Furthermore, for those cells that were exposed to both zero $\mathrm{K}^{+}$and zero $\mathrm{Na}^{+}$solu- tions, $\mathrm{E}_{\mathrm{Cl}^{-}}$was considerably more negative in zero $\mathrm{K}^{+}$solutions than in zero $\mathrm{Na}^{+}$solutions (Fig. 6A). In some cases, switching to zero $\mathrm{K}^{+}$shifted $\mathrm{E}_{\mathrm{Cl}^{-}}$by tens of millivolts in as few as $15 \mathrm{~s}$ (Fig. 6B). These results are consistent with the prediction that zero external $\mathrm{K}^{+}$would prevent inward $\mathrm{Cl}^{-}$ transport through NKCC and promote outward $\mathrm{Cl}^{-}$transport through $\mathrm{KCC} 2$. Despite these effects, none of these manipulations blocked the NO-induced shift in $\mathrm{E}_{\mathrm{Cl}^{-}}$(Fig. 6, C-E). Figure $6 F$ shows that removal of co-transported ions did not cause a statistically significant $(P=0.26 ; 0.17)$ change in the magnitude of the NO-induced shift in $\mathrm{E}_{\mathrm{Cl}^{-}}$. Interestingly, a nonsignificant trend toward larger shifts was observed in the absence of co-transported ions. This may relate to an enhanced $\mathrm{Cl}^{-}$gradient between the cytosol and an internal compartment (see following text). The roles of two other known plasma membrane $\mathrm{Cl}^{-}$transport mechanisms have also been investigated. Neither 4,4'-diisothiocyanatostilbene-2,2'-disulfonic acid (DIDS, $40 \mu \mathrm{M}, n=5$ ) a $\mathrm{HCO}_{3} / \mathrm{Cl}^{-}$transport inhibitor, nor ethacrynic acid $(10 \mu \mathrm{M}, n=4)$, an inhibitor of ATPdependent, $\mathrm{Na}^{+}$-independent $\mathrm{Cl}^{-}$transport, blocked the shift in $\mathrm{E}_{\mathrm{Cl}^{-}}$(not shown).

\section{Shift in $\mathrm{E}_{\mathrm{Cl}^{-}}$is independent of extracellular $\mathrm{Cl}^{-}$}

The lack of involvement of known plasma membrane $\mathrm{Cl}^{-}$ transporters indicates that $\mathrm{NO}$ is either stimulating an unexamined $\mathrm{Cl}^{-}$transport mechanism or releasing $\mathrm{Cl}^{-}$from inside the cell. Endosomal compartments are known to maintain relatively high $\mathrm{Cl}^{-}$concentrations to offset the membrane potentials generated by inward proton pumping and endosomal acidification (Faundez and Hartzell 2004; Sonowane and Verkman 2003). To determine whether $\mathrm{NO}$ was releasing $\mathrm{Cl}^{-}$from an internal compartment, external $\mathrm{Cl}^{-}$was reduced to match
A

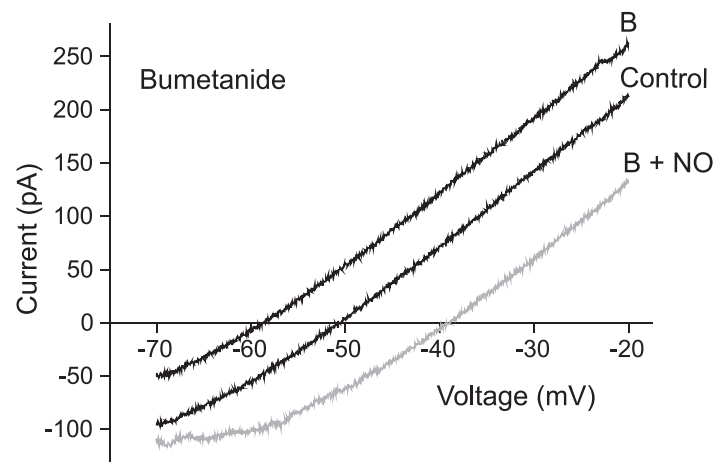

C

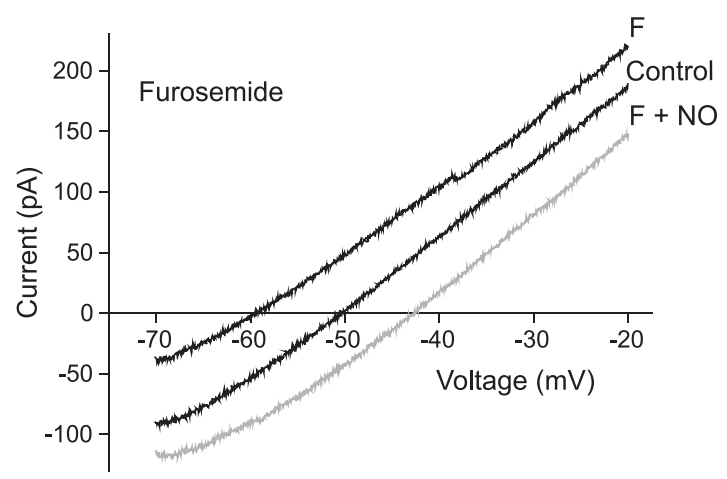

$\mathrm{B}$

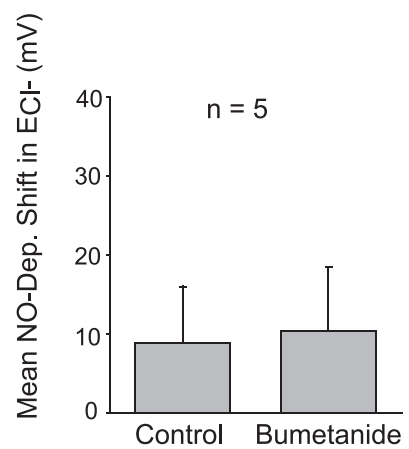

D

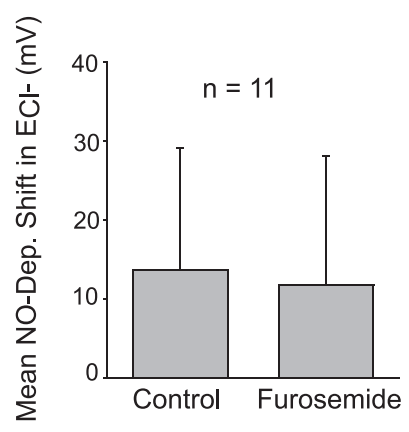

FIG. 5. Inhibition of $\mathrm{Na}^{+}-\mathrm{K}^{+}-\mathrm{Cl}^{-}$co-transporter (NKCC) and $\mathrm{K}^{+}-\mathrm{Cl}^{-}$co-transporter (KCC) $\mathrm{Cl}^{-}$co-transporters does not block the NO-induced shift in $\mathrm{E}_{\mathrm{Cl}^{-}}$. $A$ and $C$ : leak-subtracted currents from voltage ramps delivered in the presence of GABA under control conditions (no NO), in the presence of inhibitor (bumetanide (B) or furosemide (F)) and after NO exposure in bumetanide- or furosemide-containing solutions (gray trace). Records were obtained in the perforated-patch configuration with gramicidin in the pipette $\left(\mathrm{Cs}^{+}-\mathrm{B}\right.$ internal, TEA-A external). $B$ and $D: \mathrm{Cl}^{-}$co-transporter inhibitors do not significantly (bumetanide $P=$ 0.66 ; furosemide $P=0.17$ ) reduce the NOinduced shift in $\mathrm{E}_{\mathrm{Cl}^{-}}$. NO-induced shifts in $\mathrm{E}_{\mathrm{Cl}^{-}}$ in the presence of each inhibitor were compared with control applications of $\mathrm{NO}$ in the same cells. 
A

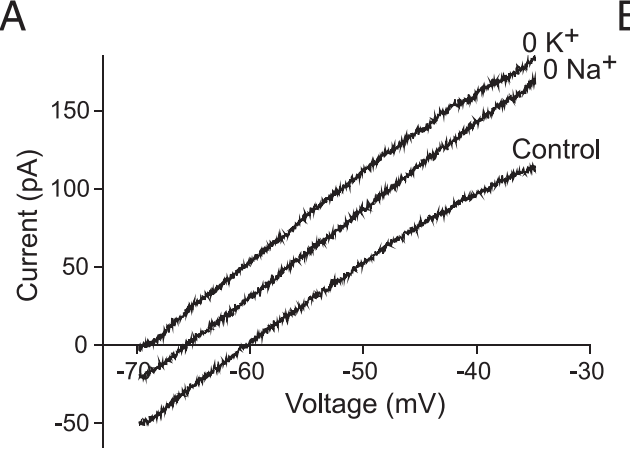

$\mathrm{C}$

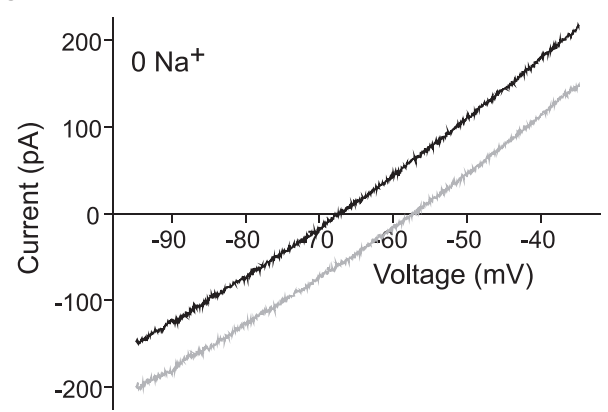

$\mathrm{E}$

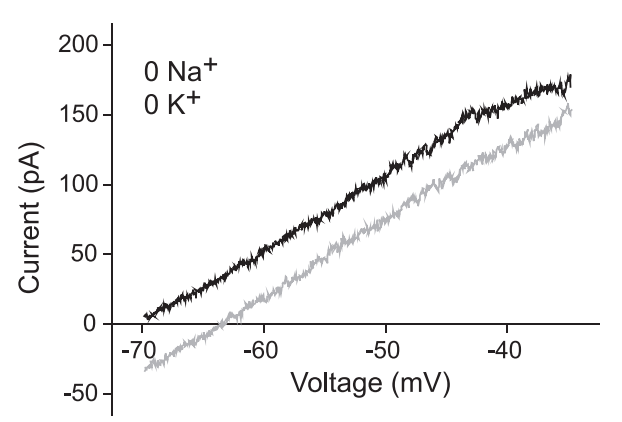

B

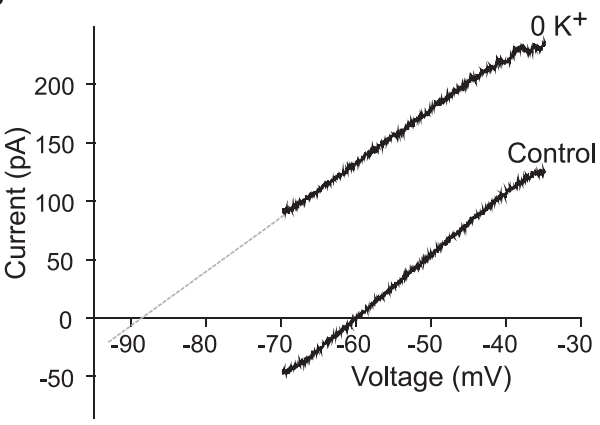

D

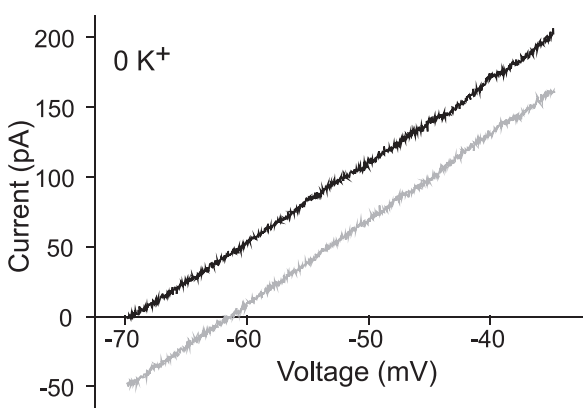

F

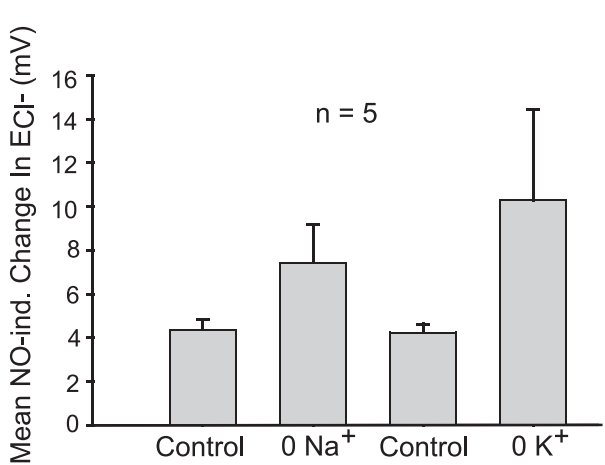

FIG. 6. Removal of co-transported ions does not block the NO-induced shift in $\mathrm{E}_{\mathrm{Cl}^{-}}$. $A-E$ : perforated-patch voltage-clamp recordings made with gramicidin $\left(\mathrm{Cs}^{+}-\mathrm{B}\right.$ internal, TEA-A external). Voltage ramps were delivered in the presence of GABA for each condition and leak-subtracted currents are shown. $A$ : $\mathrm{E}_{\mathrm{Cl}^{-}}$is negatively shifted in external solutions lacking $\mathrm{K}^{+}$or $\mathrm{Na}^{+}$. Overall, the shift from normal solutions was greater in solutions with 0 external $\mathrm{K}^{+}$than in solutions with 0 external $\mathrm{Na}^{+} . B$ : switching from normal to $0 \mathrm{~K}^{+}$external solutions can produce large negative shifts in $\mathrm{E}_{\mathrm{Cl}^{-}}$. Dotted gray trace shows estimated $\mathrm{E}_{\mathrm{Cl}^{-}}$in 0 external $\mathrm{K}^{+}$. Zero $\mathrm{K}^{+}$external solution was applied for $15 \mathrm{~s}$ before collecting the $0 \mathrm{~K}^{+}$trace. $C-E$ : Bathing the cells in $0 \mathrm{Na}^{+}, 0 \mathrm{~K}^{+}$, or 0 $\mathrm{Na}^{+} / \mathrm{K}^{+}$external solutions did not prevent the NO-induced shift in $\mathrm{E}_{\mathrm{Cl}^{-}}$(gray traces). $F$ : average $\mathrm{NO}$-induced shifts in $\mathrm{E}_{\mathrm{Cl}^{-}}$for cells bathed in $0 \mathrm{Na}^{+}$or $0 \mathrm{~K}^{+}$external solutions are not significantly different from control $(0$ $\left.\mathrm{Na}^{+}, P=0.17 ; 0 \mathrm{~K}^{+}, P=0.26\right)$. the internal $\mathrm{Cl}^{-}$concentration $(14.2 \mathrm{mM})$. NO was applied while cells were held at the reversal potential for $\mathrm{Cl}^{-}$. Under these conditions, subsequent records collected during pulses of GABA demonstrated that the NO-induced redistribution of $\mathrm{Cl}^{-}$persisted in the absence of an electrochemical gradient for chloride across the plasma membrane (Fig. 7A, see also Fig. $2 C$ ). To determine whether external $\mathrm{Cl}^{-}$was required at all, $\mathrm{NO}$ was also applied in the absence of external $\mathrm{Cl}^{-}$. For these experiments (Fig. 7B), control ramps $(B i)$ and the NO applications (Bii) were conducted in zero $\mathrm{Cl}^{-}$external solution. The arrival of $\mathrm{NO}$ in zero $\mathrm{Cl}^{-}$was marked by the presence of the NO-dependent inward current (asterisk). After switching to normal $\mathrm{Cl}^{-}$external solution (TEA-A), so that the reversal potential of the current could be measured, another set of ramps was delivered (Biii). Values for the reversal potentials of the GABA-gated currents after NO application (mean shift: $26.6 \pm 9.9 \mathrm{mV}, n=9$ ) indicate that an increase in internal $\mathrm{Cl}^{-}$ occurred in the absence of external $\mathrm{Cl}^{-}$. Control experiments were performed in the same manner but without NO application (Fig. 7, $D$ and E). Only slight fluctuations $(1-2 \mathrm{mV})$ in reversal potential resulted from just switching between $0 \mathrm{Cl}^{-}$ external and normal external solutions.
The switch back to normal external $\mathrm{Cl}^{-}$concentration before measuring the GABA-gated current reversal potentials leaves open the possibility that rapid $\mathrm{Cl}^{-}$influx could occur just prior to measuring the reversal potential. To avoid this possibility, we also examined the large NO-induced change in the amplitude of the GABA-gated currents at $-70 \mathrm{mV}$ that results from the positive shift in reversal potential. In this way, the effects of $\mathrm{NO}$ can be evaluated without re-introducing external $\mathrm{Cl}^{-}$. In this experiment, both $\mathrm{NO}$ and GABA are applied in zero external $\mathrm{Cl}^{-}$. Substantial increases $(2.9 \pm$ 0.7 -fold) in the GABA-gated current amplitude were observed in all cells tested $\left(\mathrm{n}=5\right.$; Fig. $8 A$ ). Because external $\mathrm{Cl}^{-}$is absent for both the NO injection and the enhancement of the GABA-gated current, the $\mathrm{Cl}^{-}$must be coming from the inside of the cell. Why, in the absence of internal and external $\mathrm{Cl}^{-}$ (Fig. 3B), did the NO-induced release of $\mathrm{Cl}^{-}$from internal stores not produce an inward GABA-gated current? It is plausible that under $\mathrm{Cl}^{-}$-free conditions, the $\mathrm{Cl}^{-}$store becomes depleted. Clearly, much remains to be understood about the dynamics of intracellular $\mathrm{Cl}^{-}$fluxes.

Aside from the removal of both internal and external $\mathrm{Cl}^{-}$, the only manipulation that blocked the NO-induced shift in 
A

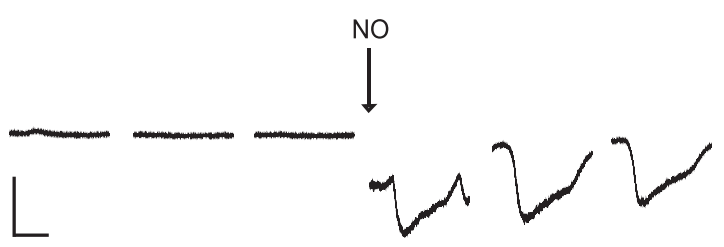

B

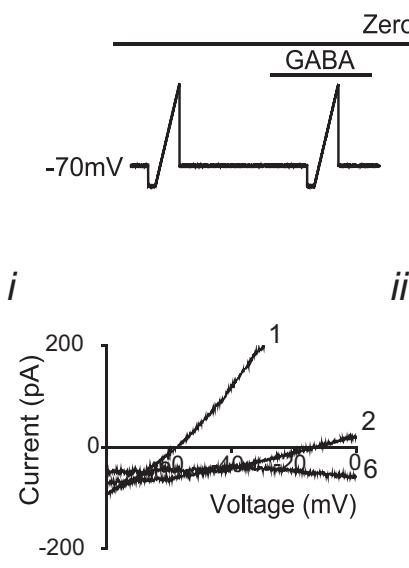

Zero $\mathrm{Cl}^{-}$
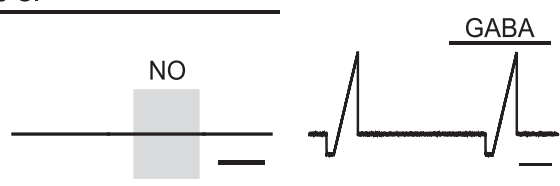

ii

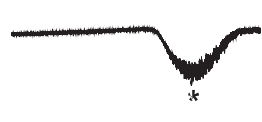

C

$\mathrm{D}$
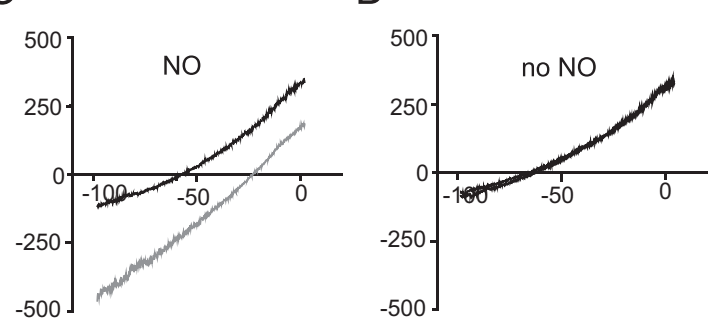

iii

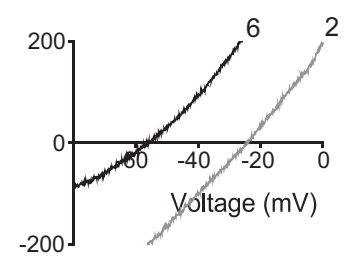

E

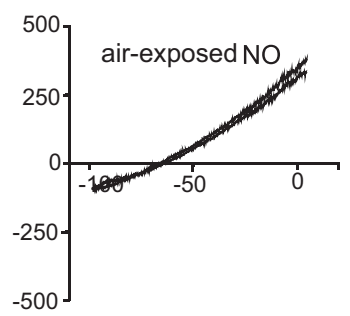

FIG. 7. External $\mathrm{Cl}^{-}$is not required for the NO-induced shift in $\mathrm{E}_{\mathrm{Cl}^{-}}$. A : representative cell held at $\mathrm{E}_{\mathrm{Cl}^{-}}(0 \mathrm{mV})$ and pulsed with GABA (horizontal bars) before and after NO application $\left(\mathrm{Cs}^{+}-\mathrm{A}\right.$ internal, low $\mathrm{Cl}^{-}$external, rupturedpatch). Increase in leak current after NO application is due to contamination from the NO-dependent current (not shown). Scale bars are 200 pA, 100 ms. Time scale applies only to current traces shown (start-to-start time, $6 \mathrm{~s}$ ). B, top: voltage protocol for $i-i i i$. The 1 st ramp of each pair is for leak subtraction. Ramp pairs were delivered 6 times (startto-start time, $10 \mathrm{~s}$ ). Scale bars are $2 \mathrm{~s}$ and $200 \mathrm{~ms}$. Bi: GABA-gated current collected in $\mathrm{O} \mathrm{Cl}^{-}$solution. Currents from 3 of the 6 voltage ramps are shown and are numbered in order of collection. The outward currents disappear as external $\mathrm{Cl}^{-}$washes out of the bath. The inward current persists but becomes progressively smaller in amplitude. This is likely due to depletion of internal $\mathrm{Cl}^{-}$during the 6 GABA exposures. Bii: NO-dependent current (asterisk) indicates the arrival of $\mathrm{NO}$ in $0 \mathrm{Cl}^{-}$solution. Biii: currents elicited after $\mathrm{NO}$ application in normal $\mathrm{Cl}^{-}$external (gray trace, 2nd ramp pair; black trace, sixth ramp pair). $C-E$ : control data recorded from a different cell. The voltage protocol shown in $B$ is used but data are shown from the $3 \mathrm{rd}$ phase of the experiment only (ramps delivered after switching back to normal external $\mathrm{Cl}^{-}$). $C$ : NO-induced shift is elicited after $\mathrm{NO}$ application in $\mathrm{O} \mathrm{Cl}^{-}$as in Biii to show that this cell is responsive to NO. $D$ : in the same cell as $C$, no change in $\mathrm{E}_{\mathrm{Cl}^{-}}$is induced by switching from $0 \mathrm{Cl}^{-}$to normal $\mathrm{Cl}^{-}$alone. $E$ : after the same sequence of events, air-exposed $\mathrm{NO}$ produces no shift in $\mathrm{E}_{\mathrm{Cl}^{-}}$.
$\mathrm{Cl}^{-}$distribution was to raise the internal $\mathrm{Cl}^{-}$concentration to $114 \mathrm{mM}$. Under these conditions, application of NO produced virtually no shift in the reversal potential of the GABA-gated currents (mean shift $=0.5 \pm 0.2 \mathrm{mV}, n=5$, Fig. 8B). This result is consistent with internal $\mathrm{Cl}^{-}$release if the $114 \mathrm{mM}$ internal $\mathrm{Cl}^{-}$reduces the gradient for $\mathrm{Cl}^{-}$between an internal $\mathrm{Cl}^{-}$compartment and the cytoplasm.

\section{$\mathrm{NO}$-induced shift in $\mathrm{E}_{\mathrm{Cl}^{-}}$is not confined to the avian retina}

Does the NO-induced shift in $\mathrm{Cl}^{-}$distribution rely on an amacrine cell-specific mechanism or is the underlying mechanism more widely expressed? To explore this, we made similar recordings from cultured rat hippocampal neurons. We find that $\mathrm{NO}$ also induces a shift in $\mathrm{E}_{\mathrm{Cl}^{-}}$in hippocampal neurons (Fig. 9A; mean shift $38 \pm 19.6 \mathrm{mV}, n=6$ ). An inward GABA-independent/NO-dependent current was also observed in hippocampal neurons (Fig. 9C, asterisk). To determine whether the shift in $\mathrm{E}_{\mathrm{Cl}^{-}}$was also due to internal release of $\mathrm{Cl}^{-}$, we repeated the experiment shown in Fig. $7 \mathrm{~B}$. Removal of extracellular $\mathrm{Cl}^{-}$during $\mathrm{NO}$ application did not inhibit the shift in $\mathrm{E}_{\mathrm{Cl}^{-}}$, suggesting that, as for amacrine cells, NO stimulates the release of $\mathrm{Cl}^{-}$from an internal store in hippocampal neurons (Fig. 9D).

\section{I S C U S S I O N}

These results indicate that NO can modulate GABAergic signaling through two distinct mechanisms. Prolonged and moderate $(\sim 100 \mathrm{nM})$ release of $\mathrm{NO}$ from donors enhances GABA-gated currents by modifying receptor activity. Brief pulses of higher concentrations of NO (hundreds of nanomolar to low micromolar, NO-bubbled solutions) produce sGC-independent increases in intracellular $\mathrm{Cl}^{-}$and shift $E_{\mathrm{GABA}}$ to more positive potentials. Furthermore, we show that the shift in the $\mathrm{Cl}^{-}$reversal potential occurs at synaptic sites and is sufficient to promote excitation at GABAergic synapses. Finally, our results indicate that the redistribution of $\mathrm{Cl}^{-}$underlying this change results from a release of $\mathrm{Cl}^{-}$from an internal compartment.

\section{Role of NO in the retina}

Measurements indicate that the concentration of NO at the cell in NO-bubbled solutions is in the hundreds of nanomolar to low micromolar range. Is this range of concentrations relevant to the levels of NO generated in the retina? NO electrode measurements at the inner retinal surface yield values ranging from 6 to $15 \mu \mathrm{M}$ (Donati et al. 1995; Groppe et al. 2003). Consistent with the electrode measurements, a biochemical assay (the Griess method) also shows retinal NO produc- 
A

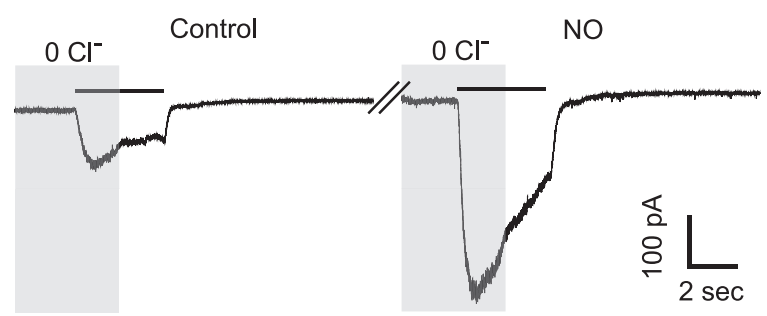

B

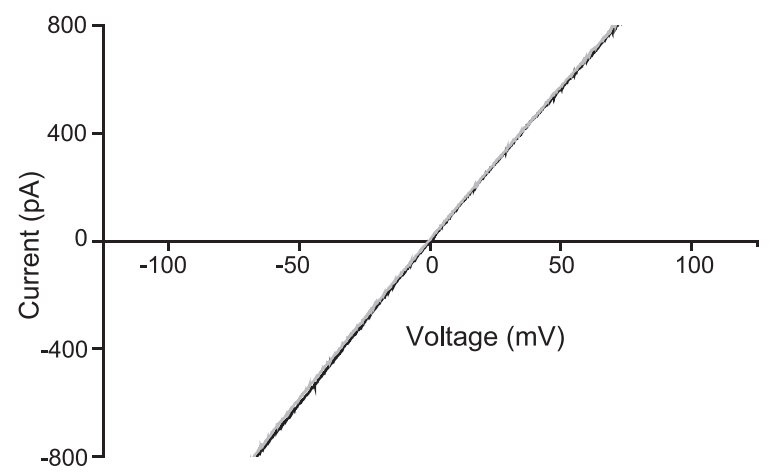

FIG. 8. NO promotes release of $\mathrm{Cl}^{-}$from an internal source. $A$ : voltageclamp recording is shown from a representative amacrine cell held at $-70 \mathrm{mV}$ (normal internal, TEA external). In the control panel, the external solution was switched to $0 \mathrm{Cl}^{-} \sim 90 \mathrm{~s}$ before the pulse of GABA. In this experiment, the rapid perfusion method usually used to apply GABA (METHODS) was used to switch between normal and 0 external $\mathrm{Cl}^{-}$. The return to normal external $\mathrm{Cl}^{-}$ reduces the size of the current due to the reduction in driving force on $\mathrm{Cl}^{-}$. In the same cell, the protocol was repeated with an $\mathrm{NO}$ injection delivered into 0 $\mathrm{Cl}^{-}$external $15 \mathrm{~s}$ before the onset of GABA delivery. The NO-dependent current was observed but is not plotted. The amplitude of the GABA-gated current is enhanced $\sim 3.5$-fold, consistent with a substantial positive shift in $\mathrm{E}_{\mathrm{Cl}^{-}} . B$ : GABA-gated currents recorded with high $\mathrm{Cl}^{-}$internal (TEA-B external, predicted $\mathrm{E}_{\mathrm{Cl}^{-}}=0 \mathrm{mV}$ ) before (black trace) and after (overlapping gray trace) NO.

tion well into the micromolar range (Heiduschka and Thanos 1998). These intraocular measurements indicate that NO concentrations can be substantial and that the doses of NO used in our experiments are within the physiological range.

Recently, NO electrode measurements have been made near the surface of an individual cell in the ganglion cell layer of the

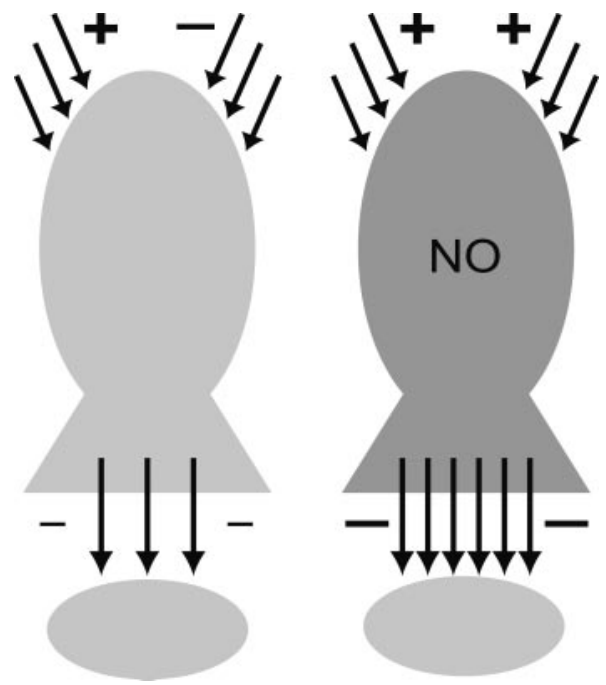

FIG. 10. Model for NO effects on amacrine cell signaling. An nNOSexpressing GABA- or glycinergic amacrine cell receiving both inhibitory and excitatory input generates a moderate inhibitory output (left). After $\mathrm{NO}, \mathrm{E}_{\mathrm{Cl}^{-}}$ shifts positive (darker shading), all inputs become excitatory, and inhibitory output from the amacrine cell is enhanced. The cells depicted are highly simplified in that amacrine cell synaptic inputs and outputs are not typically segregated.

turtle retina (Eldred and Blute 2005). An NO concentration of $\sim 200 \mathrm{nM}$ was detected. It is important to note, however, that imaging of NMDA-stimulated NO production in the same retina has demonstrated that the NO signals generated are often highly localized to individual cells and even discrete boutons in the inner synaptic layer (Blute et al. 2000). This observation suggests that some of the downstream effects of NO signaling occur primarily in nNOS-expressing cells and their immediate synaptic partners, where NO concentrations would be higher.

How might the NO-induced changes we show for cultured amacrine cells affect GABAergic signaling between amacrine cells in the inner retina? The diversity of synaptic partners and complex synaptic arrangements of amacrine cells in the IPL (Dowling and Boycott 1965; Hartveit 1999; Kolb 1997; Marc and Liu 2000) complicate this issue. The cartoon in Fig. 10 depicts a simplified subset of interactions in the inner retina. The cell on the left is a GABAergic or glycinergic, nNOS-
A

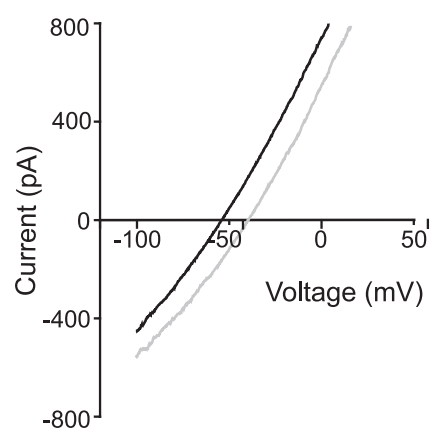

B

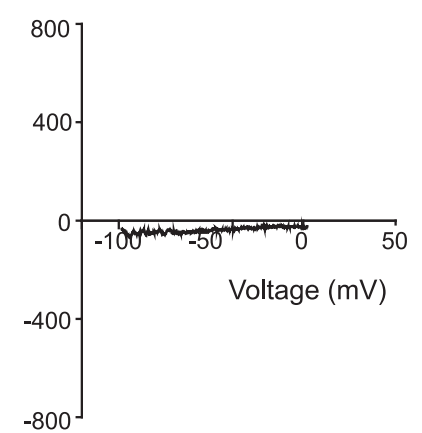

C

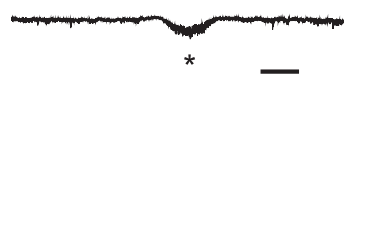

D

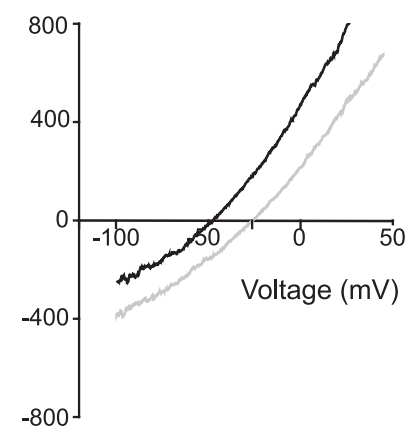

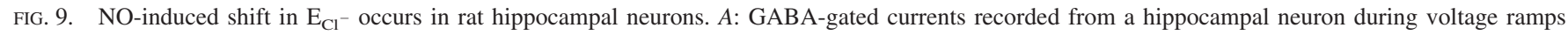

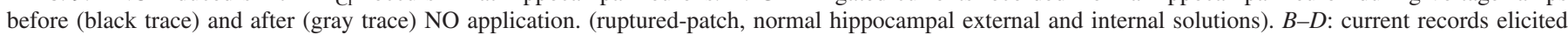

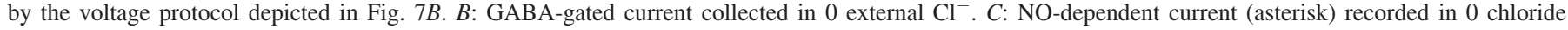

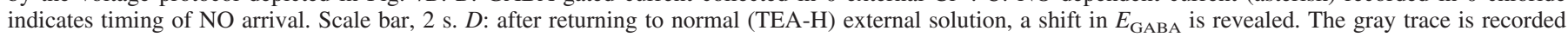

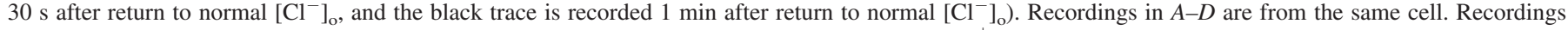
were made in the ruptured-patch configuration with TEA-H or $0 \mathrm{Cl}^{-}-\mathrm{H}$ external solutions and $\mathrm{Cs}^{+}-\mathrm{H}^{-}$internal solution. 
expressing amacrine cell that receives a mixture of excitatory (glutamatergic, from bipolar cells) and inhibitory (GABAand/or glycinergic, from other amacrine cells) inputs. The net effect of these inputs is to determine the strength of the inhibitory output from the cell onto its postsynaptic partners (ganglion cells, bipolar cells, and/or amacrine cells). If the cell is exposed to a relatively high concentration of NO (presumably via its own nNOS activity), the distribution of chloride shifts in that amacrine cell so the balance of its input becomes more excitatory and the inhibitory output of this cell is enhanced. Consistent with this proposal, Wang et al. (2003) demonstrate an NO-dependent suppression of ganglion cell light responses that is due to alterations in presynaptic (probably amacrine cell) input. This observation would be consistent with an NO-dependent shift in the amacrine cell $\mathrm{E}_{\mathrm{Cl}^{-}}$that results in an enhancement of inhibitory output onto ganglion cells.

\section{Potential source of internal $\mathrm{Cl}^{-}$}

Our results indicate that the NO-induced redistribution of $\mathrm{Cl}^{-}$is due to $\mathrm{Cl}^{-}$release from inside the cell. Endosomal compartments are a potential source of internal $\mathrm{Cl}^{-} \cdot \mathrm{Cl}^{-}$is thought to enter these compartments as a counter ion for protons being pumped in by vacuolar proton pumps (Sonawane and Verkman 2003). Movement of $\mathrm{Cl}^{-}$across endosomal membranes is thought to be mediated by the CLC family of $\mathrm{Cl}^{-}$transport proteins. ClC3-7 are found on intracellular membranes (for review, see Faundez and Hartzell 2004; Jentsch et al. 2002). Of these, $\mathrm{ClC} 3$ may be the most relevant because it is highly expressed in the brain and has been shown to be expressed on endosomes, including synaptic vesicles. Interestingly, knockouts of the CIC3 gene resulted in marked tissue degeneration specifically in the hippocampus and the retina (Stobrawa et al. 2001). Although physiological evidence for a role for CLC transport proteins in the NO-induced shift in $\mathrm{E}_{\mathrm{Cl}^{-}}$ awaits further experimentation, we have found that a polyclonal antibody raised against a conserved peptide from $\mathrm{ClC} 3$ gives an intense and punctuate labeling pattern that appears to be located intracellularly (McMains and Gleason, unpublished observations). It may be that the efflux of $\mathrm{Cl}^{-}$from endosomes via $\mathrm{ClC} 3$ contributes to the NO-induced shifts in $E_{\mathrm{GABA}}$ and $E_{\text {glycine }}$ and the transitions between inhibition and excitation.

Interestingly, $\mathrm{NO}$ has been shown to reversibly inhibit the vacuolar proton pump through $S$-nitrosylation (Forgac 1999). Although the mechanism by which NO stimulates $\mathrm{Cl}^{-}$efflux is not yet known, given the established relationship between proton pumping and $\mathrm{Cl}^{-}$movement across endosomal membranes, it is plausible that proton flux is somehow involved. However the $\mathrm{Cl}^{-}$efflux is achieved, the demonstration that it does occur and that it may be a broadly expressed mechanism is sure to impact our view of GABA and glycine-dependent synaptic signaling in the CNS.

\section{A C K N O W LED G M E N T S}

We thank M. Wilson for valuable discussions about this work, R. Moore and F. Garza for use of a nitric oxide electrode, and H. Ding for generosity in providing nitric oxide-bubbled solutions.

\section{G R A N T S}

This work was supported by a Louisiana State Board of Regents Fellowship and Sigma Xi Grant in Aid of Research to E. McMains and National Eye Institute Grant R01 EY-12204 to E. Gleason.

\section{REFERENCES}

Ahern GP, Klyachko VA, and Jackson MB. cGMP and s-nitrosylation: two routes for modulation of neuronal excitability by NO. Trends Neurosci 25 : $510-517,2002$.

Biscoe TJ and Duchen MR. The anion selectivity of GABA-mediated post-synaptic potentials in mouse hippocampal cells. $Q J$ Exp Physiol 70: 305-312, 1985.

Bormann J, Hamill OP, and Sakmann B. Mechanism of anion permeation through channels gated by glycine and gamma-aminobutyric acid in mouse cultured spinal neurones. J Physiol 385: 243-86, 1987.

Blute TA, Lee MR, and Eldred WD. Direct imaging of NMDA-stimulated nitric oxide production in the retina. Vis Neurosci 17: 557-566, 2000.

Blute TA, Mayer B, and Eldred WD. Immunological and histochemical localization of nitric oxide synthase in the turtle retina. Vis Neurosci 14: 717-729, 1997.

Blute TA, Strang C, Keyser KT, and Eldred WD. Activation of the cGMP/nitric oxide signal transduction system by nicotine in the retina. Vis Neurosci 20: 165-176, 2003.

Cudeiro S and Rivadulla C. Sight and insight: on the physiological role of nitric oxide in the visual system. Trends Neurosci 22: 109-116, 1999.

Chun M, Oh S, Kim I, and Kim K. Light and electron microscopical analysis of nitric oxide synthase-like immunoreactive neurons in the rat retina. Vis Neurosci 16: 379-389, 1999.

Crousillac S, LeRouge M, Rankin M, and Gleason E. Immunolocalization of TRPC channel subunits 1 and 4 in the chicken retina. Vis Neurosci 20: 453-463, 2003.

Davis KL, Martin E, Turko IV, and Murad F. Novel effects of nitric oxide. Aпnи Rev Pharmacol Toxicol 41: 203-236, 2001.

Donati G, Pournaras CJ, Munoz JL, Poitry S, Poitry-Yamate CL, and Tsacopoulos M. Nitric oxide controls arteriolar tone in the retina of the miniature pig. Invest Ophthalmol Vis Sci 36: 2228-2237, 1995.

Dowling JE and Boycott BB. Neural connections of the retina: Fine structure of the inner plexiform layer. Cold Spring Harb Symp Quant Biol 30: 393-402, 1965.

Eldred WD and Blute TA. Imaging of nitric oxide in the retina. Vis Res 45: 3469-3486, 2005.

Faundez V and Hartzell HC. Intracellular chloride channels: determinants of function in the endosomal pathway. Science STKE 233: 1-8, 2004.

Fischer AJ and Stell WK. Nitric oxide synthase-containing cells in the retina, pigmented epithelium, choroid, and sclera of the chick eye. J Comp Neurol 405: 1-14, 1999.

Forgac M. The vacuolar $\mathrm{H}^{+}$-ATPase of clathrin-coated vesicles is reversibly inhibited by S-Nitrosoglutathione. J Biol Chem 274: 1301-1305, 1999.

Gavrikov KE, Dmitriev AV, Keyser KT, and Mangel SC. Cation-chloride cotransporters mediate neural computation in the retina. Proc Natl Acad Sci USA 100: 16047-16052, 2003.

Gleason E, Borges S, and Wilson M. Synaptic transmission between pairs of retinal amacrine cells in culture. J Neurosci 13: 2359-2370, 1993.

Groppe M, Thanos S, Schuhmann W, and Heiduschka P. Measurement of nitric oxide production by the lesioned rat retina with a sensitive nitric oxide electrode. Anal Bioanal Chem 376: 797-807, 2003.

Hartveit E. Reciprocal synaptic interactions between rod bipolar cells and amacrine cells in the rat retina. J Neurophysiol 81: 2923-2936, 1999.

Heiduschka $\mathbf{P}$ and Thanos S. NO production during neuronal cell death can be directly assessed by a chemical reaction in vivo. Neuroreport 9: 40514057, 1998.

Hoffpauir BK and Gleason EL. Activation of mGluR5 modulates GABA receptor function in retinal amacrine cells. J Neurophysiol 88: 1766-1776, 2002.

Hölscher C. Nitric oxide, the enigmatic neuronal messenger: its role in synaptic plasticity. Trends Neurosci 20: 298-303, 1997.

Huang RQ and Dillon GH. Effect of extracellular pH on GABA-activated current in rat recombinant receptors and thin hypothalamic slices. J Neurophysiol 82: 1233-1243, 1999.

Huba $\mathbf{R}$ and Hofmann HD. Transmitter-gated currents of GABAergic amacrine-like cells in chick retinal cultures. Visual Neurosci 6: 303-314, 1991.

Huba R, Schneider H, and Hofmann HD. Voltage gated currents of putative GABAergic amacrine cells in primary cultures and in the retinal slice preparation. Brain Res 577: 10-18, 1992.

Isomura Y, Sugimoto M, Fujiwara-Tsukamoto Y, Yamamoto-Muraki S, and Yamada J. Synaptically activated $\mathrm{Cl}^{-}$accumulation responsible for depolarizing GABAergic responses in mature hippocampal neurons. $J$ Neurophysiol 90: 2752-2756, 2003. 
Jentsch TJ, Stein V, Weinreich F, and Zdebik AA. Molecular structure and physiological function of chloride channels. Physiol Rev 82: 503-568, 2002.

Kakazu Y, Uchida S, Nakagawa T, Akaike N, and Nabekura J. Reversibility and cation selectivity of the $\mathrm{K}^{+}-\mathrm{Cl}^{-}$cotransport in rat central neurons. J Neurophysiol 84: 281-288, 2000.

Kim I, Lee E, Kim K, Ju W, Oh S, Joo C, and Chun M. Immunocytochemical localization of nitric oxide synthase in the mammalian retina. Neurosci Lett 267: 193-196, 1999.

Kolb H. Amacrine cells of the mammalian retina: neurocircuitry and functional roles. Eye 11: 904-923, 1997.

Langado L. Retinal processing: amacrine cells keep it short and sweet. Curr Biol 8: R593-R600, 1998.

Marc RE and Liu W. Fundamental GABAergic amacrine cell circuitries in the retina: nested feedback, concatenated inhibition, and axosomatic synapses. J Comp Neurol 425: 560-582, 2000.

Mills SL and Massey SC. Differential properties of two gap junctional pathways made by AII amacrine cells. Nature 377: 734-737, 1995.

Neal M, Cunningham J, and Matthews K. Selective release of nitric oxide from retinal amacrine and bipolar cells. Invest Ophthalmol Vis Sci 39: 850-853, 1998.

Payne JA, Rivera C, Voipio J, and Kaila K. Cation-chloride co-transporters in neuronal communication, development and trauma. Trends Neurosci 26: 199-206, 2003.

Ríos H, López-Costa JJ, Fosser NS, Brusco A, and Saavedra JP. Development of nitric oxide neurons in the chick embryo retina. Brain Res Dev Brain Res 120: 17-25, 2000.

Rogers PA, Eide L, Klungland A, and Ding H. Reversible inactivation of $E$. coli endonuclease III by nitric oxide via modification of its [4Fe-4S] cluster. DNA Repair 2: 809-817, 2003.

Russell JM. Sodium-potassium-chloride cotransport. Physiol Rev 80: 211276, 2000.
Shin D, Lee H, Kim H, Lee E, Lu K, Lu W, Cho S, and Burk S. In situ localization of neuronal nitric oxide synthase (nNOS) mRNA in the rat retina. Neuroscience Lett 270: 53-55, 1999.

Sonawane $\mathbf{N}$ and Verkman A. Determinants of $\left[\mathrm{Cl}^{-}\right]$in recycling and late endosomes and Golgi complex measured using fluorescent ligands. J Cell Biol 160: 1129-1138, 2003.

Staley K, Smith R, Schaack J, Wilcox C, and Jentsch T. Alteration of GABAA receptor function following gene transfer of the CLC-2 chloride channel. Neuron 17: 543-551, 1996.

Stamler JS, Toone EJ, Lipton SA, and Sucher NJ. (S) NO signals: translocution, regulation and a consensus motif. Neuron 18: 691-696, 1997.

Stobrawa SM, Breiderhoff T, Takamori S, Engel D, Schweizer M, Zdebik AA, Bösl MR, Ruether K, Jahn H, Draguhn A, Jahn R, and Jentsch T. Disruption of ClC-3, a chloride channel expressed on synaptic vesicles, leads to a loss of the hippocampus. Neuron 29: 185-196, 2001.

Taylor R and Vaney D. New directions in retinal research. Trends Neurosci 26: 379-385, 2003.

Vardi N, Zhang LL, Payne JA, and Sterling P. Evidence that different cation choride cotransporters in retinal neruons allow opposite responses to GABA. J Neurosci 20: 7657-7663, 2000.

Wang G-Y, Liets LC, and Chalupa LM. Nitric oxide differentially modulates ON and OFF responses of retinal ganglion cells. J Neurophysiol 90: 1304-1313, 2003.

Wexler EM, Stanton PK, and Nawy S. Nitric oxide depresses $\mathrm{GABA}_{\mathrm{A}}$ receptor function via coactivation of cgmp-dependent kinase and phosphodiesterase. J Neurosci 18: 2342-2349, 1998.

Zheng J, Lee S, and Zhou ZJ. A developmental switch in the excitability and function of the starburst network in the mammalian retina. Neuron 44: 851-864, 2004. 